\title{
FACTORS AFFECTING THE SUCCESS OF POSYANDU FOR THE ELDERLY IN INDONESIA: A SYSTEMATIC REVIEW
}

\author{
Deasy Stefani Tinambunan'1), Adik Wibowo' \\ 1) Study Program of Health Service Management, \\ Faculty of Public Health, Universitas Indonesia \\ 2) Faculty of Public Health, Universitas Indonesia
}

\begin{abstract}
Background: Life expectancy in Indonesia has increased, with an average of 71 years. It means that the number of elderly populations has also increased. Integrated Health Post (Posyandu) for the elderly is necessary for maintain the health among elderly. The coverage of Posyandu for the elderly visit is the indicator of the success of Posyandu. The morbidity and mortality will be decreased if the elderly often visit the Posyandu. However, there is still a lack coverage of elderly who visiting Posyandu (<70\%). This study aimed to systematically review the factors affecting the success of Posyandu for the elderly in Indonesia.

Subjects and Methods: This was a systematic review conducted by searching articles from Google Scholar database. The inclusion criteria were namely articles published in 2009 to 2019 years, cross sectional design study, and using quantitative method. The study subjects were elderly who visited the Posyandu, research locations in Indonesia. The exclusion criteria were articles that did not available in full text and located not in Indonesia.

Results: Eighteen articles were obtained, all studies showed that the coverage of Posyandu for the elderly visit was less than $70 \%$. The factors that influenced the success of the Posyandu for the elderly were age, sex, occupation, knowledge, access, needs, support of cadres/ health personnel, family support, attitude, and education. Eleven articles stated that family support was associated with the success of the Posyandu for the elderly.

Conclusion: Family support is needed to increase the success of the Posyandu for the elderly. Health workers are needed to be active in socializing the importance of utilizing Posyandu for the elderly.
\end{abstract}

Keywords: elderly, integrated health post, Indonesia

\section{Correspondence:}

Deasy Stefani Tinambunan. Study Program of Health Service Management, Faculty of Public Health, Universitas Indonesia, Depok, West Java, Indonesia. Email: tdeasystefani@ymail.com. Mobile: 085271551861.

\section{BACKGROUND}

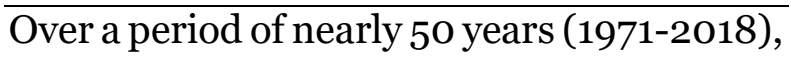
the percentage of Indonesia's elderly population has doubled. In 2018, the percentage of the elderly reached $9.27 \%$ or around 24.49 million people (BPS, 2018). According to Soeweno, a country is said to have an old structure if it has an elderly population above 7\% (Ministry of Health, 2017). This shows that Indonesia is a country with an aging population structure (Abikusno, 2005).

According to Law No. 13 of 1998, an elderly person is someone who has reached the age of 60 years and above (Sya'diyah, 2018). Globally, the elderly population is growing faster than the younger population. The percentage of elderly people in Indonesia is dominated by young elderly (age group 6069 years) with the percentage reaching $63.4 \%$, the rest are middle aged people (age group 70-79 years) by $27.9 \%$, and elderly (age group $80+$ ) by $8.7 \%$ (BPS, 2018).

The increase of the number of elderly populations can have both positive and negative impacts. The positive impact is if the elderly population is in a state of independence, health, active and productive. On the

The $6^{\text {th }}$ International Conference on Public Health Best Western Premier Hotel, Solo, Indonesia, October 23-24, 2019 | 119 https://doi.org/10.26911/the6thicph-FP.02.02 
other hand, the negative impact is when they become a burden. It is when the elderly has a problem of declining health resulting in an increase in the cost of health services, decreesed income and increased disability (Sincihu et al., 2018). Therefore, to minimize the negative impact, there is a program under the guidance of the health center, namely the Posyandu for the elderly. Posyandu for the elderly is the development of government policy through health services for the elderly which involves the participation of the elderly, family members, community leaders, and social organizations in its implementation. The goal of the posyandu for the elderly is for the elderly populations group to be ready to face old age independently and healthy (Ministry of Health Republic of Indonesia, 2016).

The target of the posyandu for the elderly as referred to in the Regulation of the Minister of Home Affairs/ Permendagri No. 19 of 2011 Article 6 is aimed at pre elderly (45-59 years), elderly people (>6o years), high risk elderly people $>70$ years old (Sya'diyah, 2018). Elderly services at the posyandu include checking daily activities, weighing, measuring height, measuring blood pressure, health education, simple laboratory tests (blood sugar levels, uric acid, cholesterol), mental and emotional status checks-up, simple treatments, and referral efforts if needed (Ministry of Health, 2013).

Elderly people will biologically experience a continuous aging process, with a marked decrease in physical endurance making it vulnerable to disease that can cause death (Ministry of Health, 2017). The elderly will also become vulnerable as they age, if their education level is low, socioeconomic status is low, and, often not a married person ( $\mathrm{Ng}$ et al., 2010). The elderly morbidity rate in 2018 is $26 \%$ (BPS, 2018). It means that from 100 elderly, there are 25 to 26 elderly who are sick. In the past four years, the morbidity rate for the elderly has continued to decline. However, the decline is relatively not too large (BPS, 2018). Basic Health Research data (2018) showeds that the prevalence of non-communicable diseases has increased. The diseases that are often experienced by the elderly are diabetes, hypertension, and stroke. The increase in the prevalence of noncommunicable diseases is related to lifestyle, such as smoking, alcohol consumption, lack of physical activity, and lack of fiber consumption (Ministry of Health, 2018).

Various attempts were made to maintain the health of the elderly, both by the elderly who were sick independently, and by their families. In addition to health services, the posyandu also provides social, religious, education, skills, sports, and cultural arts and other services needed by the elderly in order to improve their quality of life through improving their health and well-being. Therefore, the posyandu is very much in accordance with the concept of healthy and active aging that was initiated by WHO (WHO, 2017). The aging process should be accompanied by the ability and awareness of the elderly in presenting a role to be actively involved in the utilization of health services/ posyandu. Factors affecting the behavior of seeking health services in the elderly are related to health facilities, distance, knowledge, poverty, attitudes of health personnel, care processes, living alone and one's needs to take him to the hospital (Baral and Sapkota, 2018). Various other factors that influence service utilization behavior according to Lawrance Green described three main factors of health behavior. Predisposing factors include knowledge, attitudes, traditions, and beliefs in things relating to health. Enabling factors include the availability of health facilities, ownership of health insurance, availability of health personnel. Strengthening factors include attitudes and beha- 
vior of community leaders, health personnel including applicable regulations.

The success of the posyandu for the elderly can be seen from the scope of visits to use the posyandu services. However, in reality the implementation of the Posyandu for the elderly in almost all regions in Indonesia still faces various problems, namely, the low coverage of the use of the Posyandu for the elderly in each region (minimum service standard $<70 \%$ ). This study aims to systematically review the factors that influence the success of the posyandu for the elderly in Indonesia.

\section{SUBJECTS AND METHOD}

\section{Study Design}

This study is a systematic review conducted by searching for articles from the Google Scholar database with the keywords "posyandu for the elderly", "utilization factors", and "activeness of the elderly". The found article was read carefully to see whether the article meets the writer's inclusion criteria for use as literature.

\section{Inclusion and Exclusion Criteria}

The inclusion criteria are articles published from 2009 to 2019 that can be accessed, full paper in pdf format and free. The research design was included in a systematic review using quantitative methods with cross sectional design. The study was conducted in Indonesia and the subjects are the elderly who use posyandu services for the elderly.

\section{Data Extraction}

In the initial stage of the search, 6,870 articles were obtained using the keyword "posyandu for the elderly", then issued based on the last 10 years published, from 2009 to 2019, produced 6,490 articles. Then it was filtered again with more specific keywords "utilization factors" and "elderly activeness" resulted in 441 articles. Later the results were filtered again based on titles and abstracts, and the results obtained were 45 articles and finally 18 articles were selected based on the full text and assessed for eligibility.

\section{RESULTS}

Obtained in 18 articles were the coverage of the use of posyandu for the elderly in various cities in Indonesia which tends to be low and has not reached the minimum services standard target of $<70 \%$. The average attendance of the elderly every month to the posyandu started from $0.7 \%$ to $51.38 \%$. Based on Sulistiyawati's study (2012) in Jember, there is an posyandu for the elderly that has the lowest utilization coverage because there are several obstacles in the implementation of the posyandu for the elderly including poor elderly knowledge, low level of education, lack of economy, and lack of social support.

Rusmin et al. (2017) also stated that the number of inactive elderlies is greater than the active elderly. This is due to the access factor, where when access is easy, the level of activeness of the elderly in utilizing the posyandu for the elderly increases compared to difficult access. In the study of Anggraini et al. (2016) in Ngentak Hamlet, even in October 2014, only 2 people came to the posyandu. The elderly said that the reason was because work is more important and has not felt complaints of pain. The attitude of the elderly towards the use of posyandu for the elderly in Indonesia is still not positive. The consider that aging/elderly is common and does not need to undergo any examination (Hidayat et al., 2018). 


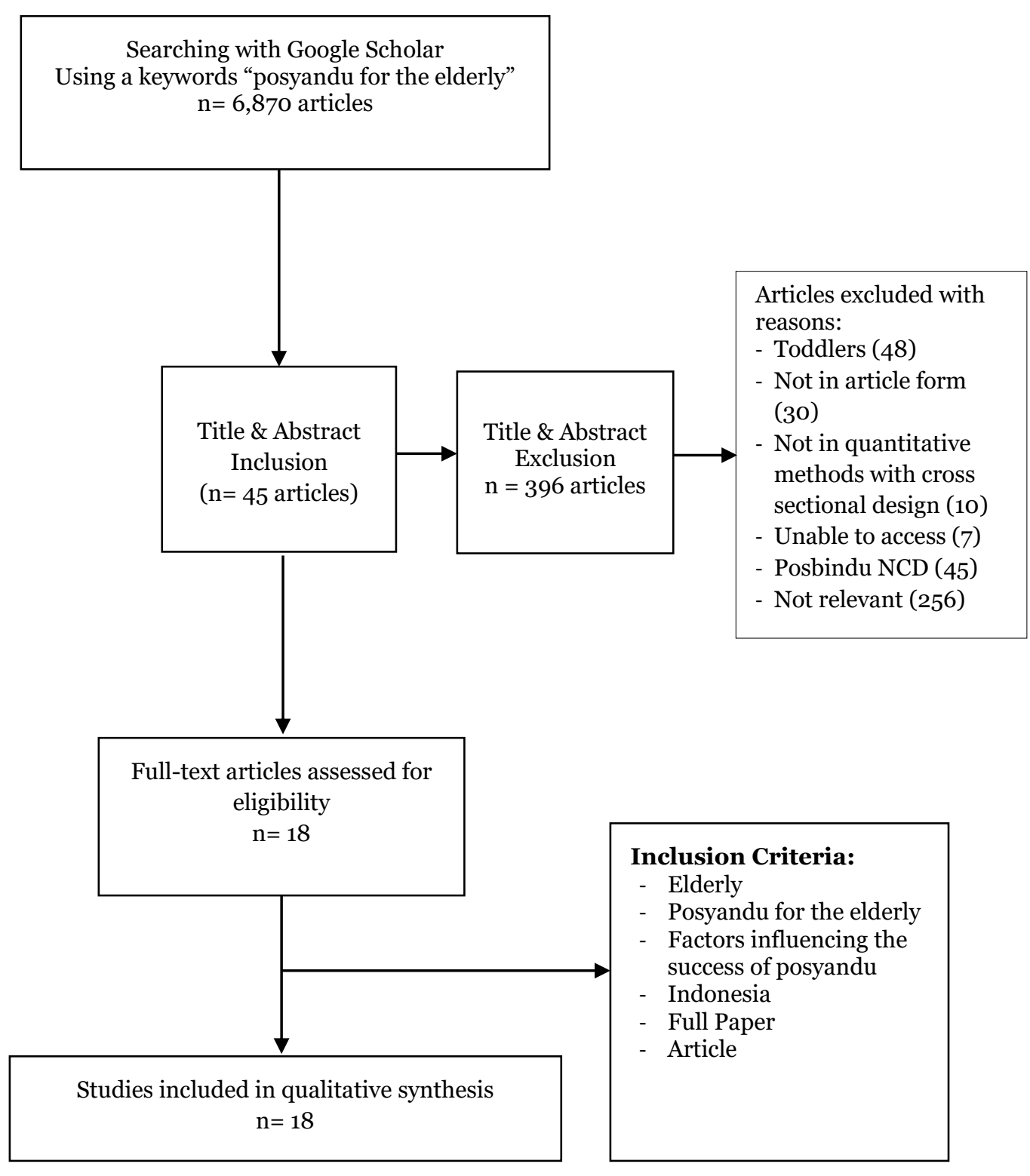

Figure 1. Flowchart of PRISMA Methods

This means that there were variations in the factors that influence the use of posyandu for the elderly in Indonesia. These factors included age, gender, education, occupation, knowledge, access, needs, attitudes, cadre support, and family support. Of these factors, the most significant influence on the use of posyandu services for the elderly is family support.

This is also proven by the study conducted by Mengko et al. (2015) in Manado, which stated that the elderly who had no family support tended not actively utilize the posyandu services, compared to those who received family support. Posyandu activities in Manado are carried out in the church, delivered during worship activities, so that all informations are known to the entire congergation including those who have elderly family members. This is where the role of the family is needed to remind elderly family members.

A study by Purnawati et al. (2014) in Mojolaban, also stated that family support

The $6^{\text {th }}$ International Conference on Public Health Best Western Premier Hotel, Solo, Indonesia, October 23-24, 2019 | 122 https://doi.org/10.26911/the6thicph-FP.02.02 
was the most influential factor in elderly visits to posyandu.Viewed demographically, the elderly in urban areas tend to be larger in number compared to the elderly in rural areas. They are dominated by elderly 60-69 years. This was proven by Triana's study (2016) in Jambi which stated that there were 836 elderly people who were registered at the Posyandu, but there were 405 elderly who visited actively.

In addition, Yusnita's (2016) study in Roworejo Village showeds that there were only 231 elderly registered and 30-50 active elderly.

A study by Purnama et al. (2018) also showeds the low number of elderly visits in rural areas in 2017, namely in Tikopo Village where the number of elderly people registerred was 63 people, and only 8-12 people were active every month. This means that the interest in visiting elderly in urban areas is higher than in elderly in rural areas. This is due to the low level of education, poor knowledge, lack of family support and difficult access to posyandu for the elderly in rural areas.

\section{DISCUSSION}

The posyandu for the elderly is the center of community activities in the form of health services for the elderly. The success of posyandu for the elderly is based on the scope of utilization of the posyandu for the elderly.

\section{Age}

Elderly classification according to the Ministry of Health can be divided into pre-elderly (45-59 years), elderly (6o-69 years), and high-risk elderly (>70 years with health problems) (Ratnawati, 2017). According to Green (2005), age is one of the demographic factors that influence a person's behavior. The age factor has an influence on the use of posyandu for the elderly services.This is evidence from research conducted by Arimby and Apriningsih (2016) which stateds that there is a significant relationship between age and elderly visits to posyandu. In this study it was seen that the age of young elderly $(<60$ years) visited the posyandu more than elderly (>60 years). This is in line with research conducted by (Purnawati et al., (2014) which also stateds that there is a significant relationship between age and posyandu for the elderly visits.

However, what is different in this study is the visit to posyandu for the elderly which is more dominated by the elderly compared to the young elderly. The young elderly feels strong and healthy, and only go to the Posyandu if they feel sick. The older the elderly become, the more health care is used (CHSRF, 2011).

Old age is an age that is susceptible to disease. The results of a study from Susenas (2018) showed that half of the elderly in Indonesia experience health complaints and the percentage increases with age. This is dominated by the elderly group (57.45\%) who experience health complaints and use more health services compared to young age (BPS, 2018). Therefor an aging population can be expected to produce an increasing need for health care (UNFPA, 2014).

\section{Gender}

According to Green (2005), besides age, gender is also one of the sociodemographic factors that influence a person's behavior. Sullivan and Thomson (1993) stated that women report more illnesses and submit their complaints to doctors than men (Sari, 2013).In the use of posyandu for the elderly, women tend to have more active behavior to participate in the posyandu for the elderly than for men, this is because elderly women are more concerned about the health conditions of the body than older men. Elderly women are more diligent in finding informations and solutions to health problems in old age (Intarti and Khoriah, 2018). 
This is an evidence by research conducted (Arimby and Apriningsih, 2016) which stated that there is a significant relationship between gender and posyandu for the elderly visits. Most of the respondents in this study who utilized the services of the posyandu for the elderly were women. This is due to the notion that the posyandu for the elderly is only for elderly women only. In addition, it is also due to the assumption of elderly men that health checks regularly will not guarantee they are not sick (Melita and Nadjib, 2018).

\section{Education}

According to Green (2005), in addition to age and gender, education is also one of the sociodemographic factors that influence one's behavior. The education level of the elderly population in Indonesia is still not good, in general, most of the elderly have low education. One third of them did not graduate from elementary school. Around 17\% of the elderly have never attended school.

In fact, this figure is still greater than the percentage of elderly people who have a high school diploma / equivalent and higher (BPS, 2018). The low level of education makes it difficult for the elderly to receive counseling provided by extension workers. This is proven by a study conducted by Sofiana et al. (2018) in which the respondents surveyed were mostly elderly with low levels of education stated that not high levels of education indicated a lack of respondents' knowledge and understanding of health. The influence of the level of education as a system has an influence in the formation of attitudes because both of them lay the foundation of individual knowledge and moral concepts.

Lower educated individuals (elementary schools) have lower knowledge so they do not know the benefits of the Posyandu for the elderly. Therefore, a low level of education must be balanced with the provision of health knowledge so that their health insight is improved, for example by health education (Sofiana et al., 2018).

This is contrary to a study conducted by Arimby and Apriningsih (2016) which stated that respondents' formal education level is indeed low, but a low level of education will not always prevent someone from learning from other media, such as television, newspapers, magazines, radio, and other people experience. This situation is reflected in the respondents whose education level is low, but the respondents still want to participate in the posyandu for the elderly activities.

\section{Occupation}

The employment variable does not necessarily have a direct effect on the utilization of health services, but rather as a motivating factor to create a desire to utilize health services.

In accordance with a study Purnawati et al. (2014), the respondents who made the most use of the posyandu services for the elderly were the elderly who did not work. Older people who work tend to be busier and feel less important to visit the Posyandu for the elderly, compared to older people who do not work and have more time to visit.

\section{Knowledge}

According to Green's theory (2005), knowledge is one of the predisposing factors or drivers that influence the behavior of one's health service utilization. It is explained that the increase in knowledge is not always the cause of changes in someone's behavior, but is closely related to the initial determinant of someone's behavior. This is an evidence in the research conducted by Sudarmi, 2017: and Bukit, 2019 which showed that the elderly who have less knowledge tend to be less active in the posyandu activities of the elderly compared to those who have better knowledge. This is because knowledge forms the perception of the elderly towards posyan$\mathrm{du}$ for the elderly, if the knowledge is good, 
then the perception will also be good and will motivate the elderly to visit the posyandu.

Based on the results of the research and theory above, it can be concluded that the higher the knowledge of the elderly about the benefits and existence of the Posyandu for the elderly, the increasing number of elderly people who use the Posyandu.

However, this contradicts research conducted by Yuniati (2014) which stated that there is no relationship between knowledge and the use of Posyandu for the elderly, which is possible because the behavior of posyandu utilization is also influenced by other factors such as attitudes, information obtained, experience, and socioeconomic.

\section{Access}

Utilization of health services refers to the accessibility and affordability of households to utilize services related to health. According to Green's (2005) theory, access is an enabling characteristic that influences the behavior of utilizing one's health services. This is a condition that allows people to use health services, or at least be ready to use them.

Rusmin et al. (2017) stated that the distance to access health services will affect the activeness of the elderly to the Posyandu for the elderly. There is a tendency for the elderly to be less active in posyandu due to long distances and expensive costs. If access to the posyandu for the elderly is easy and close, the elderly can access services by walking from their homes so that this can affect the high activity of elderly visits.

\section{Needs}

This is in line with research conducted by Arimby and Apriningsih (2016) which stated that older people who know the benefits of posyandu for the elderly tend to be more active and have a need for Posyandu for the elderly. The benefits that can be obtained by the elderly are being able to socialize with fellow seniors, get treatment and early detection of diseases easily, and get Clean and Healthy Living Behavioral knowledge.

\section{Attitude}

According to Green's (2005) theory, attitude is one of the predisposing or driving factors that influence the behavior of one's health service utilization. The attitude of the elderly is a form of the elderly's response to use the posyandu for the elderly which includes several stages: receiving, responding, respecting, and being responsible (Harahap, 2019).

Personal assessment or good attitude towards officers is the basis for the readiness or willingness of the elderly to participate in posyandu activities. With a good attitude, the elderly tends to always be present or participate in activities held at the posyandu for the elderly (Ratnawati, 2017).

Research by Mengko et al. (2015) stated that older people who have good attitudes, tend to have a good response to the use of posyandu for the elderly compared with unfavorable attitudes.

This is also in line with Yuniati's (2014) research which stated several factors that influence attitudes are personal experiences, other people considered important and cultural influences. If the individual is truly free from all pressures or obstacles that can interfere with the expression of his attitude, then it can be expected that the form of behavior that appears as a form of actual expression in this case is a visit to the posyandu.

\section{Support of Cadres/ Health Person- nel}

According to Green's (2005) theory, a reinforcing factor for a healthy behavior is based on the support of health workers such as nurses, doctors, midwives, and health cadres. This research looks at the support given by health workers to the elderly to come and take advantage of Posyandu. In the Posyandu activities, health workers are the spearhead of the community in utilizing the Posyandu for the elderly. 
In accordance with Fadhilah's study (2012), Posyandu which have active cadres have a higher chance of utilizing the Posyandu for the elderly. The ability of cadres is good in terms of education and knowledge that can be actualized properly, such as motivating the elderly to take advantage of the posyandu for the elderly by reminding return visit schedules and arriving on time to provide information about elderly health complaints.

\section{Family Support}

According to Green's (2005) theory, a person's factor for healthy behavior is based on family support. The elderly will be active in posyandu if there is encouragement from the closest person in this case their family. This may be based on the assumption that the absence of family support negatively affects the well-being of the elderly, physical, and psychological conditions. Family support is very instrumental in encouraging the interest or willingness of the elderly in participating in the posyandu for the elderly activities.

The family can be a strong motivator for the elderly if they always provide themselves to accompany and take the elderly to the posyandu, remind the posyandu schedule, and try to help solvinge problems with the elderly (Ratnawati, 2017).

Family support is the most dominant factor influencing the use of Posyandu for the elderly. This is evident from the 18 articles obtained, there are 11 articles that state family support factors have a significant influence on the use of posyandu.

In accordance with research Anggraini et al. (2016) which stateds that the family is the main support system for the elderly in maintaining their health. In this case the family is intended to support and facilitate the elderly in fulfilling their health so that they are well monitored by health workers. This is supported also by research Malawat et al. (2016) which stateds that family support is related to the interest of the elderly to visit Posyandu. Social support will be needed in difficult times or illness.

However, this study is not in line with the research of Yuniati (2014), which stated that there is no relationship between family support and the use of posyandu for the elderly, because this may occur due to lack of family resources such as income. Therefore families tend not to have time to accompany the elderly, for they are busy working.

Factors that influence the success of the posyandu for the elderly in Indonesia based on this systematic review are age, gender, occupation, knowledge, access, needs, support of cadres/ health personnel, family support, attitudes, and education. Because of the many factors that influence the success of the Posyandu for the elderly in Indonesia, it is expected that the cooperation of all parties, both the elderly, elderly families, and health personnel to be able to play an active role.

Family support is the most dominant factor influencing elderly visits to the Posyandu for the elderly each year, so it is hoped that the family will actively motivate the elderly and health personnel must be active in socializing the importance of utilizing posyandu.

\section{REFERENCES}

Abikusno N (2005). The elderly of Indonesia current policy and programmes. 15(2): 18-22.

Anggraini D, Zulpahiyana Z, Mulyanti M (2016). Faktor dominan lansia aktif mengikuti kegiatan posyandu di dusun Ngentak (dominant factors of active elderly participating in posyandu activities in Ngentak Hamlet). Jurnal Ners dan Kebidanan Indonesia, 3(3): 150. https://doi.org/10.21927/jnki.2015.3(3).150-155

Arimby AE, Apriningsih (2016). Determinan kunjungan lansia ke posbindu Senja 
Sejahtera Cinere, Depok tahun 2015 (determinant of elderly visit to posbindu Senja Sejahtera Cinere, Depok in 2015). Jurnal Kedokteran dan Kesehatan, 12 (1).

Baral R, Sapkota P (2018). Health seeking behaviour among elderly people of Bharatpur Municipality of Chitwan, Nepal. JCMS-Nepal, 14_(3): 150-153. https://doi.org/10.3126/jcmsn.v14i3.21178

BPS (2018). Statistik penduduk lanjut usia 2018 (statistics of elderly population 2018). Retrieved from https://www.bps.go.id/

Bukit RB (2019). Faktor-faktor yang mempengaruhi kunjungan posyandu lansia di Puskesmas Tenayan Raya Pekanbaru Tahun 2018 (factors that affect posyan$\mathrm{du}$ for the elderly visits at Tenayan Raya Pekanbaru Health Center in 2018). Jurnal Kesehatan Husada Gemilang, 1 (1): 32-41. https://doi.org/2615-3068

CHSRF (2011). Myth: the ageing population is to blame for uncontrollable health care costs. IJHSRP, 17(1): 20-21. https://doi.org/10.1258/jhsrp.2011.230 511

Fadhilah N (2012). Faktor-faktor yang berhubungan dengan pemanfaatan posyandu lansia di Desa Blitarejo Kecamatan GadingRejo Kabupaten Pringsewu Tahun 2012 (factors related to utilization of posyandu for the elderly in Blitarejo Village GadingRejo District Pringsewu District 2012). Jurnal Ilmiah Kesehatan, 1 (2): 26-36.

Green LW (2005). Health program planning an educational and ecological approach. New York: McGraw-Hill Companies.

Harahap NR (2019). Faktor yang berhubungan dengan pemanfaatan posyandu lansia di Wilayah Kerja Puskesmas Kambesko Tahun 2018 (factors related to utilization of posyandu for the elderly in the Kambesko Community Health
Center in 2018). Jurnal Gentle Birth, 2 (1): $28-35$.

Hidayat S, Baequni A, Inayah M (2018). Analisis determinan yang mempengaruhi keaktifan lanjut usia pada pelaksanaan posyandu lansia (determinant analysis that affects elderly activities in the implementation of Posyandu for the elderly). Jurnal Litbang Kota Pekalongan, 14: 59-70.

Intarti WD, Khoriah SN (2018). Faktorfaktor yang mempengaruhi pemanfaatan posyandu lansia (factors that influence utilization of Posyandu for the elderly). Health Stud, 2(1): 110-122. https://doi.org/10.31101/jhes.439

Kemenkes RI (2013). Gambaran kesehatan lanjut usia di Indonesia (overview of elderly health in Indonesia). https://doi.org/10.1192/bjp.111.479.1009-a

Kemenkes RI (2016). Situasi lanjut usia (lansia) di Indonesia. Retrieved from http://www.depkes.go.id/resources/do wnload/pusdatin/infodatin/infodatin lansia 2016.pdf

Kemenkes RI (2017). Situasi lansia di Indonesia tahun 2017: gambar struktur umur penduduk Indonesia tahun 2017. In Pusat Data dan Informasi.

Kemenkes RI (2018). Potret sehat Indonesia dari Riskesdas 2018 (Healthy portrait of Indonesia from Riskesdas 2018)._Retrieved from http://=www.depkes.go.id/article/view/18110200003/potret-sehat-indonesia-dari-riskesdas2018.html

Malawat R, Supriyanto, Fitriasari E (2016). Faktor-faktor yang berhubungan dengan minat lansia terhadap pelayanan posyandu lansia (factors related to elderly interest in posyandu for the elderly services). GHS, 1(1): 13-23.

Melita, Nadjib M (2018). Faktor-faktor yang berhubungan dengan kunjungan lansia ke posbindu lansia di wilayah kerja 
puskesmas kelurahan Bintara Kota Bekasi tahun 2017. Jurnal Kebijakan Kesehatan Indonesia, 07 (04): 158-167. Mengko VV, Kandou G, Massie RG (2015). Pemanfaatan posyandu lansia di wilayah kerja Puskesmas Teling atas Kota Manado. JIKMU, 5 (2): 479-490.

Ng N, Hakimi M, Byass P, Wilopo S, Wall S. (2010). Health and quality of life among older rural people in Purworejo District, Indonesia. Global Health Action, 3(1): 78-87.

https://doi.org/10.3402/gha.v3io.2125

Purnama S, Sudirman, Yusuf H (2018). Faktor yang berhubungan dengan pemanfaatan posyandu lansia desa Tikopo Kecamatan Bokat Kabupaten Buol (factors related to elderly interest in posyandu for the elderly services). Jurnal Kolaboratif Sains, 1 (1): 700-710.

Purnawati N, Irdawati, Yuniartika W (2014). Faktor-faktor yang mempengaruhi kunjungan lansia dalam kegiatan posyandu Di Desa Plumbon Kecamatan Mojolaban Sukoharjo (factors that affect elderly visits in posyandu activities in Plumbon Village, Mojolaban Sukoharjo District). 1-13. Retrieved from http://eprints.ums.ac.id//30723/17/Naskah_Publikasi_Deal.pdf

Ratnawati E (2017). Asuhan keperawatan gerontik. Edisi pertama (Gerontik Nursing Care (1st ed.). Yogyakarta: Pustaka Baru Press.

Rusmin M, Bujawati E, Habiba N (2017). Faktor-faktor yang berhubungan dengan di wilayah kerja Puskesmas Somba Opu Kabupaten Gowa tahun 2015 (factors related to the working area of the Somba Opu Health Center in Gowa Regency 2015). Al-Sihah Public Health Journal, 9(1): 9-18.

Sari D (2013). Faktor yang berhubungan dengan kunjungan lansia ke posyandu lansia di Kecamatan Bayah Kabupaten
Lebak tahun 2012-2013 (factors related to elderly visits to posyandu for the elderly in Bayah Sub-District, Lebak Regency in 2012-2013). Universitas Indonesia.

Sincihu Y, Maramis WF, Rezki MN (2018). Improving elderly's quality of life through family role. In Jurnal Kesehatan Masyarakat, 3.

Sofiana J, Qomar UL, Astuti DP (2018). Faktor-faktor yang mempengaruhi kunjungan lansia ke posyandu di Desa Semali Sempor Kebumen (factors that influence elderly visit to Posyandu in Semali Village, Sempor Kebumen). Jurnal Ilmiah Kesehatan Keperawatan, 14(2): 67-71.

Sudarmi (2017). Faktor-faktor yang berhubungan dengan pemanfaatan posyandu lansia di wilayah kerja Puskesmas Pesisir Tengah Kabupaten Pesisir Barat Provinsi Lampung (factors related to the utilization of Posyandu Elderly in the Work Area of Pesisir Tengah Public Health Center, Pesisir Barat Regency Lampung Province). Jurnal Kesehatan Metro Sai Wawai, 8-14.

https://doi.org/10.3386o/jik.v13i1.170

Sulistiyawati I (2012). Hubungan antara pekerjaan, pendapatan, pengetahuan sikap lansia dengan kunjungan ke posyandu lansia (the relationship between employment, income, knowledge of elderly attitudes with visits to posyandu elderly). Jurnal Ilmiah Kesehatan, 1 (2): 15-17.

Sya'diyah H (2018). Keperawatan lanjut usia teori dan aplikasi (elderly nursing theory and application). Sidoarjo: Indomedika Pustaka.

Triana W (2016). Hubungan pengetahuan, dukungan keluarga, peran petugas terhadap pemanfaatan posyandu lansia di wilayah kerja Puskesmas Koni Tahun 2015 (knowledge relationship, family 
support, role of officers in utilizing posyandu elderly in the koni Puskesmas Work Area in 2015). Jurnal Bahana Kesehatan Masyarakat, 1(2): 195-200.

UNFPA (2014). Indonesia on the threshold of population ageing (UNFPA, Ed.)

WHO (2017). World population ageing 2017highlights (ST/ESA/SER.A/397). New York: United Nations, Departement of Economic and Social Affairs, -Population Division.-Retrieved from http://www.un.org/en/development/desa/popula-
tion/publications/pdf/ageing/WPA2017 _Highlights.pdf

Yuniati YD (2014). Pemanfaatan posyandu lanjut usia (utilization of posyandu seniors). Jurnal Kesehatan Politeknik Kesehatan Palembang, 1: 30-33.

Yusnita (2016). Faktor-faktor yang berhubungan dengan keikutsertaan lanjut usia dalam kegiatan posyandu (factors related to the participation of old people in posyandu activities). Jurnal Ilmiah Kesehatan, 5(9): 699-704. 